\title{
Green Synthesis of new heterocyclic hydrazones, spectroscopic characterization
}

\section{Síntesis vía Química Verde de nuevas hidrazonas heterocíclicas, caracterización espectroscópica}

\author{
CABRERA-VIVAS, Blanca Martha $\dagger^{*}$, PALILLERO-CISNEROS, Angel, MORALES-LARA, Laura, \\ and MELÉNDEZ-BALBUENA, Lidia
}

\author{
Benemérita Universidad Autónoma de Puebla, Facultad de Ciencias Químicas, Edificio 179, 18 sur y Av. San Claudio, Col. \\ San Manuel, Puebla, México, C. P. 72001
}

ID $1^{\text {st }}$ Author: Blanca Martha, Cabrera-Vivas / ORC ID: 0000-0002-9760-5473, CVU CONACYT ID: 21743

ID $1^{\text {st }}$ Coauthor: Angel, Palillero-Cisneros / ORC ID: 0000-0002-1008-

ID $2^{\text {nd }}$ Coauthor: Laura, Morales-Lara / ORC ID: 0000-0001-5404-754X

ID $3^{\text {rd }}$ Coauthor: Lidia, Meléndez-Balbuena / ORC ID: 0000-0002-4664-5221

DOI: $10.35429 / E J E .2019 .11 .6 .1 .6$

Received September 08, 2019; Accepted November 30, 2019

\begin{abstract}
The present project analyses the synthesis of three hydrazones with new structures by Green Chemistry, for its later spectroscopic characterization. Hydrazones are organic compounds with interesting properties, such as being solids with specific melting points and colors depending on their structure. Hydrazones and substituted derivatives are a group of versatile compounds and leading molecules because they are potential bioactive agents with an ample spectrum of pharmacological activities. It is important to note that these properties are a consequence of the presence of the imine group that possess high electronic density. The objective is the synthesis of heterocyclic hydrazones derived from furan and thiophencarbaldehyde with novel structures that allow the synthesis of optimized compounds with biomedical applications. Synthesis, purification and characterization of organic compounds was designed to combat illnesses with maximum positive effects and minimum toxicity, in order to evaluate their activity in specific cell lines.
\end{abstract}

\section{Resumen}

El presente trabajo es la síntesis de 3 hidrazonas de estructura nueva, con Química Verde, y posterior caracterización espectroscópica. Las hidrazonas son compuestos orgánicos, con singularidades, como de ser sólidos con puntos de fusión característicos, color determinado dependiendo de la estructura. Las hidrazonas y sus derivados sustituidos son un conjunto de compuestos versátiles considerados moléculas líderes, por ser agentes bioactivos potenciales y con amplitud de actividades farmacológicas. Cabe recalcar, que estas propiedades se deben principalmente a la presencia del grupo imino con alta densidad electrónica. El objetivo es la síntesis de hidrazonas heterocíclicas aromáticas derivadas de furano $y$ tiofenocarbaldehído con nuevas estructuras que eficienten su síntesis, y contribuyan al desarrollo de estos compuestos con aplicaciones biomédicas. Se diseñó la síntesis, purificación y caracterización de compuestos orgánicos para combatir enfermedades con efectos máximos y toxicidad mínima, para evaluar su actividad en líneas celulares específicas.

\section{Química Verde, Hidrazonas}

\section{Green Chemistry, Hydrazones}

Citation: CABRERA-VIVAS, Blanca Martha, PALILLERO-CISNEROS, Angel, MORALES-LARA, Laura, and MELÉNDEZ-BALBUENA, Lidia. Green Synthesis of new heterocyclic hydrazones, spectroscopic characterization. ECORFAN Journal-Ecuador. 2019. 6-11: 1-6

\footnotetext{
* Correspondence to Author (email: bmcabreravivas@yahoo.com)

$\dagger$ Researcher contributing as first author.
} 


\section{Introduction}

Hydrazones with an azomethine group $\mathrm{NHN}=\mathrm{CH}$ - represent an important class of compounds that possess a wide variety of biological activities. (Al-Hazmi, et al., 2019; Corey and Enders, 1976). It is believed that the azomethine group is essential for the bioactivity of hydrazones and derivatives. (Rollas and Küçükgüzel, 2007).

Specifically, hydrazones, class of organic compounds have attracted attention of medicinal chemists because of the azomethine group bonded to a carbonyl group, which is responsable for a variety of biological activities. Several papers around the world have reported hydrazone structures in search for better activity agents against different targets with lower toxicity (Rahmet, 2012). In recent years, it has been discovered the highest antibacterial activity of the structure hidrazide-hydrazone (El-Gammal, 2019; Popiolek, et al., 2017).

In the last decades the presence of infectous diseases is on the rise. The Center for Control and Prevention of diseases (CDC) has estimated more than 2 million infections and 23,000 deaths caused by bacteria resistant to antibiotics in the USA every year and 18 drug resistant pathogens, which are considered a threat (CDC, 2013). Enterococcus faecium, Staphylococcus aureus, Acinetobacter baumannii, Pseudomonas aeruginosa and Enterobacter species are considered ESKAPE pathogens (Rice, 2008), nothing that they escape from regular antibacterial drugs. Categories of this class of pathogens: urgent, serious and distressing (Chu, et al., 2019). This fact prioritizes the search for alternative strategies to overcome antibacterial resistance between bacterial pathogens (CDC, 2013).

0.7 billion deaths take place worldwide due to drug resistant pathogens. This number may increse to 10 million by 2050 if the actual tendencies continue (Xu, et al., 2019). In addition, the overuse of drugs against infectous and non-infectous diseases has caused resistance against pathogenic bacteria, weakening the success of medication (Chopra, et al., 2008; Gao, et al., 2018).
This is why, the search for antimicrobial agents is a neverendingly task, with a relevant importance to explore and develop new and different structures that allow enhanced biological activities (Rollas, 2007), to employ them in clinical applications, or as chelating agents (Wahben, 2019). Moreover, it is also important to explore environmentally friendly methologies for their synthesis.

Hydrazones are an important class of molecules used as drugs for their biological activities such as: analgesic, anthelmintics, anticonvulsant, antidepressive, antiinflammatory, antimalarial, anticancerous and antibacterial (Rahmat, 2012).

Some antibacterial drugs available in the market are furacilina, furazolidona, ftivazida, nifuroxazida, nirofurazona y nitrofurantoine, contain a hydrazone group (Popiolek 2017).

Hydrazone derivatives have been well studied because they have been used as important precursors in the construction of several heterocyclic ring reactions (Rollas $y$ Küçükgüzel 2007).

With this evidence it is crucial to develop new antibacterial agents with an excellent activity against pathogens, which are resistant to existing drugs.

The high spectrum of biological activities combined with structural modifications and successful applications in clinic practice have inspired many researchers to the study and creation of a great deal of hydrazone derivatives.

Popiołek et al., obtained fifteen new hydrazide-hydrazones by condensation of hidrazide of isonicotinic acid with different aromatic aldehydes, confirming their structure by espectroscopic methods. All sinthetized compouds were subjected to in vitro antimicrobial essays against "Gram-negative" and "Gram- positive" bacteria and the corresponding fungus, Candida spp. Some sinthetized hydrazide-hydrazone compounds were discovered to be compounds with significant antibacterial activity and more powerful than chimiotherapeutic agentes commonly used. 


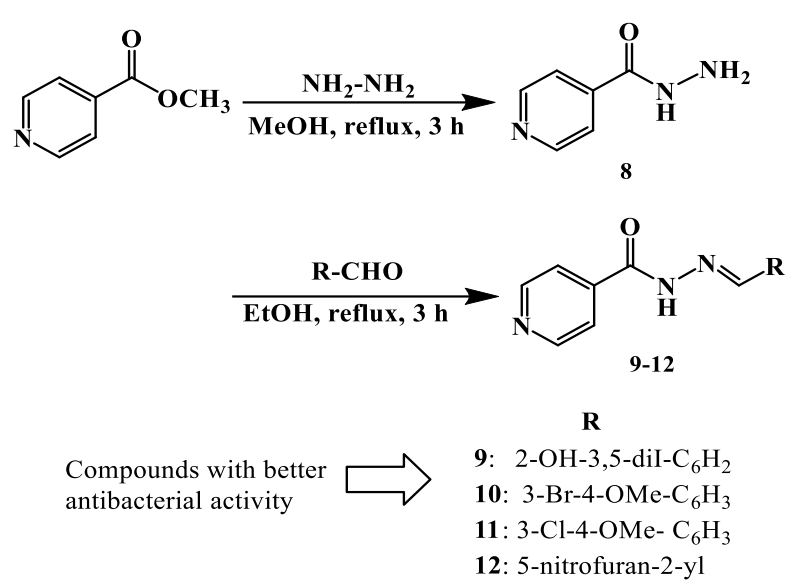

Scheme 1 Steps of the Popiołek synthesis of new acid isonicotinic hydrazide-hydrazones. Popiołek 2018

Data obtained by Popiołek et al. show that the new synthesized compounds 9-12, exhibit some sort of antimicrobial activity against reference bacteria and yeasts. Compounds 9 and 12 showed the highest antibacterial effect. Compound 9 exhibited a strong activity against all Gram-positive bacteria y bactericide effect towards Staphylococcus aureus ATCC 6538, Staphylococcus epidermidis ATCC 12228 and Bacillus subtilis ATTC 6633 and bacteriostatic effect against other bacteria. It is worthwhile mentioning compound 9 activity against $S$. aureus ATTC 25923 and M. luteus ATCC 10240 , which was 8 times and 32 times better than nitrofurantoine activity respectively.

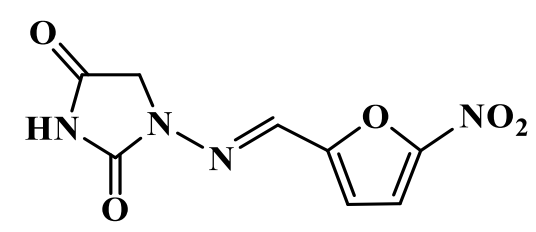

Figure 1 Structure of nitrofurantoin

The activity of this derivative was also significant against B. subtilis ATCC 6633, which was twice as high as cefuroxime activity and 8 times higher than ampiciline activity. This substance showed good bactericide activity against Gram- negative Bordetella bronchiseptica ATTC 4617. The activity against these bacteria was equal to the activity of nitrofurantoine with bactericide effect.

Compounds 10 y 11 showed moderate effect towards M. luteus ATTC 10240 and good bactericide activity against other Gram-positive bacteria. Moreover, compound 9 has a good antifungal effect towards Candida spp. (Popiołek, et al., 2018).

\section{Objective}

The main objective of this work is the synthesis, separation and purification of a hydrazone with new heterocyclic structure based on Green Chemistry, for its later characterization using spectroscopic technics such as ultraviolet-visible (UV-Vis), infrared (I. R.), hydrogen and carbon 13 magnetic resonance $\left({ }^{1} \mathrm{H} \quad \mathrm{RMN},{ }^{13} \mathrm{C} \quad \mathrm{RMN}\right)$, mass espectrometry (E. M.) and X-ray diffraction. Scheme 2 shows the synthesis under Green Chemistry of the aromatic hydrazones derived from the condensation reaction of 5-nitrofuranocarbaldehyde, thiophenecarbaldehyde thiophenecarbaldehyde diphenylhydrazine.

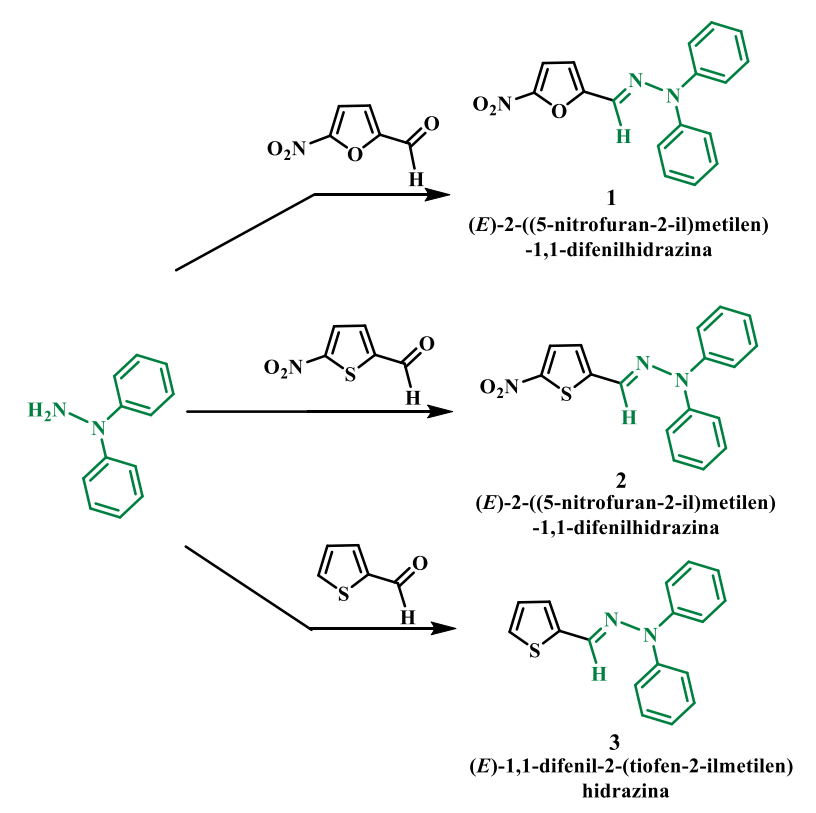

Scheme 2 Synthesis under Green chemistry conditions of hydrazones 1, 2 and 3

\section{Results}

The hydrazone-type compounds shown in this work were synthesized from $\mathrm{N}, \mathrm{N}$ diphenylhydrazine with three different aromatic heterocyclic aldehydes derived from thiophenecarboxyaldehyde and furancarboxydehyde. These reactions are carried out at room temperature and under constant stirring for several hours, depending on the reaction. The reactions were periodically monitored by thin layer chromatography. For the purification of these compounds they are allowed to crystallize and subsequently recrystallized by slow evaporation or diffusion. 
After having purified the products of the three reactions presented, their respective characterization was carried out by melting point determination by Tekno-Lab apparatus, UV-VIS spectra were recorded on on Varian Cary 50 Bio UV Visible, IR spectra were recorded on Nicolett FT-IR Magna 750, in $\mathrm{KBr}$ pellets, as the standard sample preparation technique, ${ }^{1} \mathrm{H}-\mathrm{NMR}$ and ${ }^{13} \mathrm{C}$ spectra were obteined on a Varian VX-400 spectrometer, TMS was used as internal reference; mass spectrometry E.I. with elemental analysis were recorded on JEOL JEM JMS-SX 102 a $70 \mathrm{eV}$, and X-ray diffraction data was collected with an Oxford Diffraction Gemini " $A$ " diffractometer equipped wih a CCD area detector (Agilent 2011 CrysAlis PRO). These studies were used to determine and corroborate the proposed structures of the three hydrazones 1, 2 and 3.

The results of the characterization of hydrazones are shown below.

E)-2-((5-nitrofuran-2-yl)methylene)-1,1diphenylhydrazine (1). Reddish Orange scales; yield: $82 \%$ at $25^{\circ} \mathrm{C}, \mathrm{M}$. p. $136-138^{\circ} \mathrm{C}$. UV $\lambda_{\max }=$ $440 \mathrm{~nm}$. FT. IR (film): $\left(\mathrm{cm}^{-1}\right): 3136 v\left(\mathrm{C}_{\mathrm{sp} 2}-\mathrm{H}\right)$ (furan), $3057 \vee\left(\mathrm{C}_{\mathrm{sp} 2}-\mathrm{H}\right.$ phenyl), $1558 \vee(\mathrm{C}=\mathrm{N})$, $1473 v(\mathrm{C}=\mathrm{C}), \quad 1342 \quad v\left(\mathrm{NO}_{2}\right), 1215 \quad v(\mathrm{C}-\mathrm{O}$ furan), 754, $732 \quad v(\mathrm{C}-\mathrm{H}$ monosubstituted aromatic). ${ }^{1} \mathrm{H} \quad \mathrm{NMR} \quad\left(400 \mathrm{MHz}, \quad\left(\mathrm{CD}_{3}\right)_{2} \mathrm{CO}\right.$ :

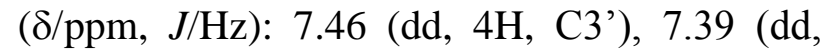
1H, C4), 7. 28 (dd, 2H, C4'), 7.19 (m, 4H, C2'), $7.00(\mathrm{~s}, 1 \mathrm{H}, \mathrm{C}=\mathrm{N}), 6.82(\mathrm{~d}, 1 \mathrm{H}, \mathrm{C} 3) .{ }^{13} \mathrm{C} \mathrm{NMR}$ (400 MHz, $\left.\left(\mathrm{CD}_{3}\right)_{2} \mathrm{CO}\right)$ : ( $\left.\delta / \mathrm{ppm}\right): 155.34(\mathrm{C} 5)$, 151.12 (C1'), 142.13 (C2), 130.07 (C3'), 125.97 (C4'), 122.68 (C2'), $122.34(\mathrm{C}=\mathrm{N})$, 114.58 (C4), 108.53 (C3). MS-EI: $307.31 \mathrm{~m} / \mathrm{z}=$ $\mathrm{C}_{17} \mathrm{H}_{13} \mathrm{~N}_{3} \mathrm{O}_{3}$.

(E)-2-((5-nitrofuran-2-yl)methylene)-1,1diphenylhidrazine (2). Bright red rhomboid scales; yield: $81 \%$ at $25^{\circ} \mathrm{C}$, M. p. $128-130{ }^{\circ} \mathrm{C}$. UV $\lambda_{\max }=465 \mathrm{~nm}$. FT. IR (film): $\left(\mathrm{cm}^{-1}\right): 3024 \mathrm{v}\left(\mathrm{C}_{\mathrm{sp} 2^{-}}\right.$ $\mathrm{H}$ thiophene $), 2916 \mathrm{v}\left(\mathrm{C}_{\mathrm{sp} 2}-\mathrm{H}\right.$ phenyl $), 1587 \mathrm{v}$ $(\mathrm{C}=\mathrm{N}), 1438 \vee(\mathrm{C}=\mathrm{C}), 1483,1325 \vee\left(\mathrm{NO}_{2}\right), 700$ $v\left(\mathrm{C}-\mathrm{H}\right.$ (monosubstituted aromatic). ${ }^{1} \mathrm{H}$ NMR (400 MHz, $\left(\mathrm{CD}_{3}\right)_{2} \mathrm{CO}:(\delta / \mathrm{ppm}, J / \mathrm{Hz}): 7.78(\mathrm{~d}$, 1H, C4), 7.46 (dd, 4H, C3'), 7. 28 (m, 2H, C4'), 7.19 (dd, 4H, C2'), 7.12 (s, 1H, C=N), 6.77(d, 1H, C3). ${ }^{13} \mathrm{C}$ NMR $\left(400 \mathrm{MHz},\left(\mathrm{CD}_{3}\right)_{2} \mathrm{CO}\right):(\delta /$ ppm): $149.99(\mathrm{C}=\mathrm{N}), 149.55 \quad(\mathrm{C} 5), 142.28$ (C1'), 130.04 (C3'), 129.38 (C4), 127.17 (C3), 125.76 (C2), 123.90 (C2'), 122.36 (C4'). MSEI: $323.37 \mathrm{~m} / \mathrm{z}=\mathrm{C}_{17} \mathrm{H}_{13} \mathrm{~N}_{3} \mathrm{O}_{2} \mathrm{~S}$.
(E)-1,1-diphenyl-2-(thiophene-2-

methylene)hidrazine (3). Light yellow powder; yield: $70 \%$ at $25^{\circ} \mathrm{C}, \mathrm{M}$. p. $164-166^{\circ} \mathrm{C}$. UV $\lambda_{\max }=$ $355 \mathrm{~nm}$. FT. IR (film): $\left(\mathrm{cm}^{-1}\right): 3099 v\left(\mathrm{C}_{\mathrm{sp} 2}-\mathrm{H}\right.$ tiophene), $3061 \quad v\left(\mathrm{C}_{\mathrm{sp} 2}-\mathrm{H}\right.$ phenyl $), 1581 \quad \mathrm{~V}$ $(\mathrm{C}=\mathrm{N}), \quad 1494 \quad v(\mathrm{C}=\mathrm{C}), \quad 756 \quad v(\mathrm{C}-\mathrm{H}$ (monosubstituted aromatic), $698 \mathrm{v}(\mathrm{C}-\mathrm{S}) .{ }^{1} \mathrm{H}$ NMR (400 MHz, $\left(\mathrm{CD}_{3}\right)_{2} \mathrm{CO}:(\delta / \mathrm{ppm}, J / \mathrm{Hz})$ : 7.41 (m, 4H, C3'), 7.14(m, 7H, C=N, C2', C4'), 6.94 (dd, 1H, C4), 6.90 (m, 1H, C3). ${ }^{13} \mathrm{C}$ NMR (400 MHz, $\left.\left(\mathrm{CD}_{3}\right)_{2} \mathrm{CO}\right)$ : $(\delta / \mathrm{ppm}): 143.28(\mathrm{C} 2)$, 141.79 (C2'), 130.36 (C5), 129.80 (C3'), 127.13 (4), $126.29(\mathrm{C} 3), 125.40(\mathrm{C}=\mathrm{N}), 124.56$ (C4'), 122.39 (C2'). MS-EI: $278.37 \mathrm{~m} / \mathrm{z}=$ $\mathrm{C}_{17} \mathrm{H}_{14} \mathrm{~N}_{2} \mathrm{~S}$.
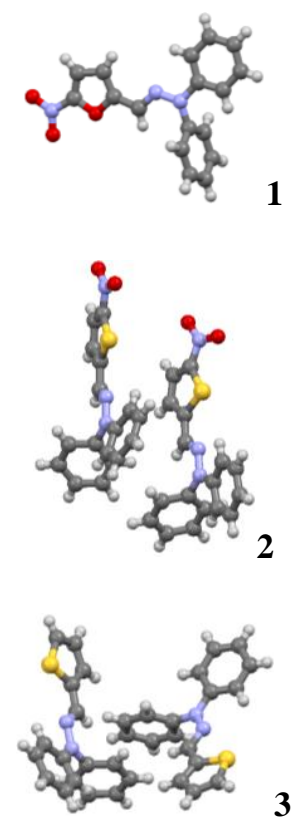

Figure 2 X-rays of the 3 synthetized hydrazones 1, 2 and 3

\section{Discussion}

Except for the synthesis of hydrazone 3, the others are considered reactions with high yields. The melting point ranges obtained show that the hydrazones are pure. The observed colors of the hydrazones agree with the values obtained from the $\lambda_{\max }$ in the Ultraviolet spectrum. The values of the bands obtained in the Infrared spectrum show that the reaction was verified, when the carbonyl band $(>\mathrm{C}=\mathrm{O})$ was absent and that of the imine bond $(>\mathrm{C}=\mathrm{N})$, corresponding to the hydrazone. In NMR the imine hydrogen appears very constant, around 7.00 ppm for the 3 hydrazones, which means that it is not being affected by the presence or absence of the nitro group. 


\section{Acknowledgements}

The authors thank VIEP-BUAP for the support granted through the BUAP-CA-152, 2019 project.

\section{Conclusions}

The 3 hydrazones were obtained with good yields and under conditions of Green Chemistry, using the same chemical equivalents for reagents and product of each reaction, from this point of view, work was carried out on efficientizing and synthesizing hydrazones using an alternative and environmentally friendly method ambient. The structures of the hydrazones were characterized, coinciding in all cases with the expected structure (This copounds are stored keeping their high purity), which will promote their possible biomedical applications in subsequent studies as possible antiparasitic or antibacterial.

\section{References}

Al-Hazmi, G. A., Abou-Melha, K. S., ElMetwaly, N. M., Althagafi I., Zaki, R., and Shabban, F. (2019). Green Synthesis for 3(Benzoylhydrazono)-N-(pyidin-2-yl)

butanamide Complexes: Spectral, Analytical, Modelling, MOE Docking and Biological Studies, Journal of Inorganic and Organometallic Polymers and Materials, 1-18. doi.org/10.1007/s10904-019-01326-6.

Ali, M.R., Marella, A., Alam, M.T., Naz, R., Akhter, M., Shaquiquz-zaman, M., Saha, R., Tanwar, O., Alam, M.M., Hooda, J. (2012). Review of biological activities of hydrazones. Indonesian J. Pharm. 23 (3), 193-202.

Chopra, I., Schofield, C., Everett, M., O’Neill, A. \& Miller, K. (2008). Treatment of healthcare-associated infections caused by Gramnegative bacteria: a consensus statement. Lancet Infect. Dis., 8, 133. doi.org/10.1016/s1473-3099(08)70018-5.

Chu, X. M., Wang, C. Liu, W., Liang, L. L., Gong, K. K., Zhao, C. Y., Sun, K. L. (2019). Quinoline and quinolone dimers and their biological activities: an overview, Eur. J. Med. Chem. 161 101-117. doi: 10.1016/j.ejmech.2018.10.035.
Corey, E. J., Enders, D. (1976). Application of $\mathrm{N}, \mathrm{N}$-dimethylhydrazones to synthesis. Use in efficient, positionally and stereochemically selective $\mathrm{C}-\mathrm{C}$ bond formation; oxidative hydrolysis to carbonyl compounds. Tetrahedron Lett. 17:11-14. doi.org/10.1016/S0040-4039(00)71307-4.

El-Gammal, O. A., El-Reash, G. A., and Bedier, R. A. (2019). Synthesis, spectoscopic, DFT, biological studies and molecular docking of oxovanadium (IV), copper (II) and iron (III) complexes of a new hydrazine derived from heterocylic hydrazyde. Aplied Organometallic Chemistry 33(10), e5141. doi.org/10.1002/aoc.5141.

Gao, C., Fan, Y. L., Zhao, F., Ren, Q. C., Wu, X., Chang, L., Gao, F. (2018). Quinolone derivatives and their activities against methicillin-resistant Staphylococcus aureus (MRSA), Eur. J. Med. Chem. 157: 1081-1095. doi: 10.1016/j.ejmech.2018.08.061.

Popiolek, L. (2017). Hydrazide-hydrazones as potential antimicrobial agents: overview of the literature since 2010. Med. Chem. Res., 26, 287301. doi.org/101007/s00044-016-1756-y.

Popiołek, Ł., Biernasiuk, A., Berecka, A.; Gumieniczek, A., Malm, A., Wujec, M. (2018). New hydrazide-hydrazones of isonicotinic acid: synthesis, lipophilicity and in vitro antimicrobial screening. Chem. Biol. Drug. Des. 91: 915-923. doi:10.1111/cbdd.13158.

Rice, L.B. (2008). Federal funding for the study of antimicrobial resistance in nosocomial pathogens: No ESKAPE. Journal of Infectious Diseases. 197, 1079-1081. doi: $10.1086 / 533452$.

Rollas, S., Küçükgüzel, S. G. (2007). Biological activities of hydrazone derivatives. Molecules. 12:1910-1939. doi.org/10.3390/12081910.

Verma, G., Marella, A., Shaquiquzzaman, M., Akhtar, M., Ali, M. R., Alam, M. M. (2014). A review exploring biological activities of hydrazones. Journal of pharmacy \& bioallied sciences. 6(2), 69-80. doi:10.4103/09757406.129170 .

Wahbeh, J., Milkowski, S. (2019). The Use of Hydrazones for Biomedical Applications. SLAS Technol. 24(2):161-168. doi: $10.1177 / 2472630318822713$.

CABRERA-VIVAS, Blanca Martha, PALILLERO-CISNEROS, Angel, MORALES-LARA, Laura, and MELÉNDEZ-BALBUENA, Lidia Green Synthesis of new heterocyclic hydrazones, spectroscopic characterization. ECORFAN Journal-Ecuador. 2019 
Xu, Z., Zhao, S. J., Lv, Z. S., Gao, F., Wang, L.

L., Zhang, F., Bai, L. Y., Deng, J. L. (2019)

Fluoroquinolone-isatin hybrids and their

biological activities, Eur. J. Med. Chem. 162:

396-406. doi: 10.1016/j.ejmech.2018.11.032. 